\title{
Autism as a disorder of biological and behavioral rhythms: toward new therapeutic perspectives
}

\section{Sylvie Tordjman ${ }^{1,2}$ *, Katherine S. Davlantis ${ }^{3}$, Nicolas Georgieff $^{4}$, Marie-Maude Geoffray ${ }^{4}$, Mario Speranza $^{5}$, George M. Anderson ${ }^{6}$, Jean Xavier ${ }^{7}$, Michel Botbol ${ }^{1,8}$, Cécile Oriol $^{2}$, Eric Bellissant ${ }^{9}{ }^{10}$, Julie Vernay-Leconte ${ }^{11}$, Claire Fougerou ${ }^{9,10}$, Anne Hespel $^{9,10}$, Aude Tavenard $^{9,10}$, David Cohen ${ }^{7}$, Solenn Kermarrec ${ }^{1,2}$, Nathalie Coulon ${ }^{1}$, Olivier Bonnot ${ }^{1}$ and Geraldine Dawson ${ }^{3}$}

1 Laboratoire Psychologie de la Perception, Université Paris Descartes, CNRS, UMR 8158, Paris, France

2 Pôle Hospitalo-Universitaire de Psychiatrie de l'Enfant et de l'Adolescent (PHUPEA), Centre Hospitalier Guillaume Régnier, Université de Rennes 1, Rennes, France

${ }^{3}$ Department of Psychiatry and Behavioral Sciences, Duke University School of Medicine, Durham, NC, USA

${ }^{4}$ Department of Child and Adolescent Psychiatry, Centre Hospitalier Le Vinatier, Lyon, France

${ }^{5}$ Department of Child and Adolescent Psychiatry, Centre Hospitalier de Versailles, Université de Versailles Saint-Quentin-en-Yvelines, Le Chensay, France

${ }^{6}$ Child Study Center, Yale University School of Medicine, New Haven, CT, USA

Department of Child and Adolescent Psychiatry, Assistance Publique - Hôpitaux de Paris, Groupe Hospitalier Pitié-Salpêtrière, CNRS FRE 2987, University Pierre and Marie Curie, Paris, France

${ }^{8}$ Service Hospitalo-Universitaire de Psychiatrie de I'Enfant et de l'Adolescent, CHU de Brest, Université de Bretagne Occidentale, Brest, France

${ }^{9}$ Clinical Investigation Center, INSERM CIC 0203, University Hospital, Rennes 1 University, Rennes, France

${ }^{10}$ Department of Clinical Pharmacology, University Hospital, Rennes 1 University, Rennes, France

${ }^{1}$ Pôle Hospitalo-Universitaire de Psychiatrie Adulte (PHUPA), Centre Hospitalier Guillaume Régnier, Université de Rennes 1, Rennes, France

Edited by:

Roberto Canitano, University Hospital of Siena, Italy

Reviewed by:

Rajshekhar Bipeta, Gandhi Medical

College and Hospital, India

Felipe Ortuño, Clínica Universidad de

Navarra, Spain

Roberto Canitano, University Hospital

of Siena, Italy

\section{*Correspondence:}

Sylvie Tordjman, Hospitalo-

Universitaire de Psychiatrie de

I'Enfant et de I'Adolescent, 154 rue de

Châtillon, Rennes 35200, France

e-mail: s.tordjman@yahoo.fr
There is a growing interest in the role of biological and behavioral rhythms in typical and atypical development. Recent studies in cognitive and developmental psychology have highlighted the importance of rhythmicity and synchrony of motor, emotional, and interpersonal rhythms in early development of social communication. The synchronization of rhythms allows tuning and adaptation to the external environment. The role of melatonin in the ontogenetic establishment of circadian rhythms and the synchronization of the circadian clocks network suggests that this hormone might be also involved in the synchrony of motor, emotional, and interpersonal rhythms. Autism provides a challenging model of physiological and behavioral rhythm disturbances and their possible effects on the development of social communication impairments and repetitive behaviors and interests. This article situates autism as a disorder of biological and behavioral rhythms and reviews the recent literature on the role of rhythmicity and synchrony of rhythms in child development. Finally, the hypothesis is developed that an integrated approach focusing on biological, motor, emotional, and interpersonal rhythms may open interesting therapeutic perspectives for children with autism. More specifically, promising avenues are discussed for potential therapeutic benefits in autism spectrum disorder of melatonin combined with developmental behavioral interventions that emphasize synchrony, such as the Early Start Denver Model.

Keywords: autism spectrum disorder, biological rhythms, motor, emotional and relational rhythms, synchronization of rhythms, melatonin, Early Start Denver Model, therapeutics

\section{INTRODUCTION}

Endogenous physiological variations involved in biological rhythms reflect adaptation to the environment. Thus, the sleepwake rhythm associated with biological circadian rhythms can be viewed as an adaptation to the day-night cycle. Circadian rhythms allow temporal organization of biological functions in relation to environmental changes (1). The periodicity of activities applies to all biological, physiological, and psychological functions; recently, the science of biological rhythms, chronobiology, has emerged with its own theory, science, and education (2).

Furthermore, recent studies in the field of cognitive and developmental psychology have highlighted the importance of rhythmicity and synchrony of motor, emotional, and relational rhythms in early development of social communication. Given the major role of the sleep hormone melatonin in the ontogenetic establishment of diurnal rhythms, the synchronization of peripheral oscillators (also termed clocks) and the regulation of human circadian rhythms (1), melatonin might be involved in the synchrony of motor, emotional, and relational rhythms.

Indeed, relationships might exist, based on the hypothesis of ergodicity (3), between cellular communication networks involving a cellular synchrony (synchronization of cellular oscillations by melatonin) and early social communication development involving a synchrony of motor, emotional, and interpersonal rhythms. Autism spectrum disorder (ASD) - a developmental disorder characterized by social communication impairments associated with repetitive interests and behaviors - provides an interesting and challenging model of abnormal melatonin production in early developmental disorders and its possible relationship with autistic behavioral impairments. 
This article proposes a central role of rhythmicity and synchrony of rhythms in typical child development and offers a new integrative approach, which considers autism as a disorder of biological and behavioral rhythms. In this perspective, promising avenues will be discussed in this article for potential therapeutic benefits in ASD of melatonin and developmental behavioral interventions that emphasize rhythms and synchronization, such as the Early Start Denver Model (ESDM).

\section{PHYSIOLOGICAL AND BEHAVIORAL RHYTHM DISTURBANCES IN AUTISM \\ AUTISM AS A DISORDER OF BIOLOGICAL RHYTHMS}

Alterations in circadian sleep-wake rhythm have frequently been reported in autism $(4,5)$. More specifically, reduced total sleep and longer sleep latency as well as nocturnal and early morning awakenings are often observed in individuals with ASD (612). Furthermore, prior studies on melatonin in autism have all reported abnormalities in melatonin secretion (see Table 1). In addition, abnormalities in cortisol circadian rhythm have also been reported in autism [for a review, see Tordjman et al. (13)]. In particular, significantly higher frequency of absence of circadian variation in melatonin and cortisol levels was observed in individuals with autism compared to typically developing controls. Golombek et al. (14) described the effects of circadian desynchronization that can enhance susceptibility to certain disorders (metabolic, immune, cognitive, and somatic disorders including cancer). It is noteworthy that congenitally blind children with consequently abnormal melatonin secretion and synchronization [the production of pineal-derived melatonin depends on the light acting through the retinohypothalamic tract (15)] very frequently display autism [up to $42 \%$ (16)], whereas hearing impaired children, including hearing loss, show autism less frequently [up to $10 \%$ (17)]. More specifically, abnormally low daytime and nighttime melatonin secretion was associated with an absence of melatonin circadian variation in some individuals with autism $(18,19)$, which in turn, given the role of synchronizer of melatonin, also has consequences on the circadian rhythms network, including the cortisol circadian rhythm $(13,20)$.

This blunted circadian rhythmicity with no or little variability might be related to the difficulties in adapting to changes typically observed in individuals with autism. Thus, children with autism who are confronted with physiological continuity due to absent circadian rhythms may have difficulties adapting to changes in either their external or their internal environment (26). Indeed, as previously underlined, the circadian clocks network, synchronized by melatonin and involving an internal system of continuity/discontinuity, allows adaptation to environmental changes.

Similarly, blunted circadian rhythmicity may explain the difficulty observed in many children with autism in adapting to

Table 1 | Studies of melatonin levels in individuals with autism.

\begin{tabular}{|c|c|c|c|c|}
\hline Study & Sample & Study group & Measured variable & Results \\
\hline Ritvo et al. (21) & Urine & $\begin{array}{l}\text { Young adults with autism } \\
(N=10)\end{array}$ & Melatonin concentration & $\begin{array}{l}\text { Increased daytime values compared to typically developing } \\
\text { controls } \\
\text { Similar nighttime values compared to typically developing } \\
\text { controls }\end{array}$ \\
\hline Nir et al. (22) & Serum & $\begin{array}{l}\text { Young men with autism } \\
(N=10)\end{array}$ & Melatonin concentration & $\begin{array}{l}\text { Increased daytime values compared to typically developing } \\
\text { controls } \\
\text { Decreased nighttime values compared to typically developing } \\
\text { controls }\end{array}$ \\
\hline $\begin{array}{l}\text { Kulman } \\
\text { et al. (19) }\end{array}$ & Serum & $\begin{array}{l}\text { Children with autism } \\
(N=14)\end{array}$ & $\begin{array}{l}\text { Melatonin concentration } \\
\text { (24-h circadian rhythm) }\end{array}$ & $\begin{array}{l}\text { Decreased nighttime values compared to typically developing } \\
\text { controls } \\
\text { No circadian variation in } 10 / 14(71.4 \%) \text { children with autism } \\
\text { Inverted rhythm in } 4 / 14(28.6 \%) \text { children with autism }\end{array}$ \\
\hline $\begin{array}{l}\text { Tordjman } \\
\text { et al. (23) }\end{array}$ & Urine & $\begin{array}{l}\text { Children and adolescents } \\
\text { with autism ( } N=49)\end{array}$ & $\begin{array}{l}\text { 6-Sulphatoxymelatonin } \\
\text { excretion rate (12-h collection) }\end{array}$ & $\begin{array}{l}\text { Decreased nighttime values compared to typically developing } \\
\text { controls }\end{array}$ \\
\hline $\begin{array}{l}\text { Melke } \\
\text { et al. (24) }\end{array}$ & Plasma & $\begin{array}{l}\text { Adolescents and young } \\
\text { adults with autism }(N=43)\end{array}$ & Melatonin concentration & $\begin{array}{l}\text { Decreased daytime values compared to typically developing } \\
\text { controls }\end{array}$ \\
\hline $\begin{array}{l}\text { Mulder } \\
\text { et al. (25) }\end{array}$ & Urine & $\begin{array}{l}\text { Children and adolescents } \\
\text { with autism }(N=20)\end{array}$ & $\begin{array}{l}\text { 6-Sulphatoxymelatonin } \\
\text { excretion rate ( } 24-h \text { collection) }\end{array}$ & $\begin{array}{l}\text { Trend to lower } 24-h \text { melatonin excretion rate in } \\
\text { hyperserotonemic compared to normoserotonemic individuals } \\
\text { with autism }\end{array}$ \\
\hline $\begin{array}{l}\text { Tordjman } \\
\text { et al. (18) }\end{array}$ & Urine & $\begin{array}{l}\text { Post-pubertal adolescents } \\
\text { and young adults with } \\
\text { autism }(N=43)\end{array}$ & $\begin{array}{l}\text { 6-Sulphatoxymelatonin } \\
\text { excretion rate (split } 24-\mathrm{h} \\
\text { collection) }\end{array}$ & $\begin{array}{l}\text { Decreased daytime values compared to typically developing } \\
\text { controls } \\
\text { Decreased nighttime values compared to typically developing } \\
\text { controls } \\
\text { No circadian variation in } 10 / 43(23.2 \%) \text { individuals with autism }\end{array}$ \\
\hline
\end{tabular}


changes in rhythms of their external and internal environment. Thus, rapid rhythms of sensory stimuli in their external environment (e.g., repeated visual stimuli provided by a stroboscopic light) can provoke epileptic seizure in some individuals with autism [approximately one-third of children with autism have epilepsy (27)]. Interestingly, EEG changes tended to be correlated with an abnormal rhythm of melatonin in young adults with autism (22). Furthermore, some parents have reported that their daughters with autism experience epileptic seizures toward the 14th day of their menstrual cycle, which is when luteinizing hormone (LH) levels peak (Tordjman, personal communication), suggesting quite tentatively that individuals with autism may have difficulties adapting to periodic hormonal changes in their internal environment. We can state the following hypothesis: a change in rhythm associated with excessive environmental stimuli might strongly increase arousal and lead to physiological stress which, for some individuals with autism, can disturb the rhythmic activity of a particular brain area, leading it to fall out of sync with the rest of the brain and causing its population of neurons to fire (depolarization and occurrence of an epileptic seizure). This underlines the importance of stable physiological rhythms.

Finally, significant relationships have been found between lower nocturnal melatonin excretion and increased severity of autistic social communication impairments, especially for verbal communication and social imitative play $(18,23)$. These findings are in agreement with studies suggesting an association between reduced melatonin production and language impairment $(22,28)$. Along the same line, the systemic administration in the animal model of Zebra Finch of a melatonin-1B receptor antagonist at the beginning of the night shortens the song and motif length and affects the song syllable lengths produced the next day (29). Reduced melatonin activity might create timing problems in biological clocks with physiological and psychological effects that might be, according to Boucher's model of autism (30) and Wimpory's theory (31), involved in autistic impairments, notably in autistic social communication impairments. It is noteworthy that deficiency in oxytocin [oxytocin is considered a bonding hormone $(32,33)$ ] has also been reported in autism $(34,35)$ and bonding is involved in the development of very early social interaction in infants. Interestingly, the release of oxytocin by the posterior pituitary gland follows a robust circadian rhythm in mammals. Further studies are needed to better understand the underlying mechanisms of oxytocin anomalies in autism and to explore, in particular, possible oxytocin rhythm disturbances in ASD. The importance of the synchrony of rhythms in the development of social interaction and communication is detailed in the next section.

\section{IMPORTANCE OF SYNCHRONY OF RHYTHMS FOR SOCIAL COMMUNICATION IN TYPICAL DEVELOPMENT AND AUTISM SPECTRUM DISORDER}

Several studies, based on animal models and human perinatal development, suggest that stable patterns of repeated stimuli in the form of maternal physiological rhythms, involving cross-modal perception such as regular cardiac rhythm, which provides the fetus with auditory and vibratory stimuli, allow the fetus to integrate sensory information facilitating prenatal perceptual learning and develop a coherent representation of his or her internal and external environment (36-38). Fluctuations in the physiological rhythms (variants), such as variations in the maternal cardiac rhythm and also variations in hormone levels involved in the circadian rhythms that are already present during the fetus life (the fetus' circadian rhythms are the mother's ones), occurring in a background of regular repetition of identical sequences (invariants), may help the fetus to develop the ability to adapt to change in an environment characterized by high regularity. As previously emphasized (38), very early mother-infant relations provide a secure environment based on the repetition of invariants, while at the same time promoting adaptation to change through the presence of variants. It is through the regular repetition of identical sequences of discontinuity, such as circadian rhythms, that a continuum is constructed associated with the development of adaptation to changes.

The development of the very earliest form of communication relies on the sharing of emotions between mother and infant, when, for example, the infant is suckling in his or her mother's arms, through emotional synchrony that enhances the integration of sensory inputs $(39,40)$. Concerning memory processes, emotions enable to "fix" events, just as a photographic fixing agent sets images (38). Cortisol (a stress and arousal neurohormone) crosses the placental barrier. The cortisol circadian rhythm, as well as the melatonin circadian rhythm in the fetus and infant after birth, are those of maternal cortisol and melatonin. Indeed, the infant's circadian cortisol and melatonin rhythms are only established between 2 and 3 months of age in typical development, at the same time that infants begin to have more regular sleep-wake cycles associated with nighttime sleep lasting 6-8 h $(41,42)$. Interestingly, this period coincides in typical development with the emergence of social smiling by the second month of life (43), the advent of mirror self-recognition at around 3 months of age (44), and increased brain activation to speech occurring between 3 and 4 months of age (45).

At birth, the human immaturity of the cerebral cortex allows initial learning to influence the neural architecture through perceptual-action mapping $(46,47)$. The infant's social skills, especially including imitation, shared attention, and empathic understanding, also contribute to the development of learning $(46,48)$. Social synchrony can be defined as the dynamic and reciprocal adaptation of the temporal structure of behaviors between interactive partners (49). In typically developing children, the quality of social interaction depends on an active dialog between the parent and the infant $(50,51)$. Numerous studies have been emphasizing the importance of parent-infant synchrony and the construction of shared timing in social communication development (52).

Also, biological markers were associated with relational synchrony. First, oxytocin administration to parent enhances infant physiological and behavioral readiness for social engagement and parallels an oxytocin increase in infants (32). Second, neural correlates were found using hyper-scanning recordings of EEG brain activity and measures of neural synchronization between distant brain regions of interacting individuals through a free imitation task (53). Dumas and colleagues' study (53) was the first to record dual EEG activity in dyads of subjects during spontaneous non-verbal interaction. Eleven same-sex pairs were scanned. They found that interpersonal rhythmic oscillations were correlated 
with the emergence of synchronization in the brain's alpha-mu band between the right centro-parietal regions (an area involved in social interaction) of both participants. Developmental psychologists now study interaction not only as the addition of two behaviors but also as a global phenomenon in which synchrony is considered as social per se. To describe the dialog between two partners engaged in behavioral and affective exchange, developmental psychologists more and more take into consideration rhythm and temporal course of both behavior and affect, regarded as key expressions of adaptation during interaction $(49,52)$.

Only a few studies have addressed the importance of infantcaregiver synchrony/reciprocity in the development of social communication involving infants who subsequently are diagnosed with autism. It appears appropriate in the field of autism to consider the combined domain of social communication, as the most recent version of the ADOS scale does, as well as the recently released DSM-5 American classification. Methods to investigate this issue include studies using early home videos (54), parental interviews focusing on early abnormalities (55), and prospective assessment of children at risk of ASD (e.g., siblings) (56, 57). Studies have revealed a pervasive developmental course in infants who were later diagnosed with ASD. Thus, the first signs were abnormalities in eye contact, imitation, disengagement, joint attention, orienting to name, and body language. These behaviors are parts of the affective tuning disturbances; the term affective tuning, defined by Stern (58) as the "execution of behaviors expressing the emotional ownership of a shared affective state," refers to infantcaregiver emotional communication based on rhythmic similarity from the second semester of life onward. Also, these behaviors are important precursors of later-developing symptoms. However, whether these first signs impair early infant-parent interactions and whether they reflect already autistic behavioral impairments in the infant remain to be explored. In two related studies based on home movies of children later diagnosed with autism, SaintGeorges et al. (54) and Cohen et al. (59) showed that motor and emotional asynchrony was present between infants and parents before 12 months of age, and parents perceived weaker initiatives from their children. In addition, parents experienced weaker interactive responsiveness from their children and increasingly tried to compensate this perceived deficit by soliciting behaviors through touching the infant. This was particularly observed after 12 months of age for the fathers of infants who were later diagnosed with autism.

Many authors have studied imitation in children with autism (imitation of other people's faces, gestures, or vocal signals) in order to better understand the development of autistic social communication impairments. This specific type of imitation is referred to as "spatial" imitation to highlight the capacity to produce an instantaneous copy of the form of the signal. However, another way to communicate with others is to perform a "temporal" imitation of their behavior (60). This is what humans do through rhythmic finger or foot taping, dancing, singing, and drumming in synchrony with others (61). Xavier et al. (62) highlighted the importance of rhythmicity and synchrony in the development of children's imitative exchanges with peers. From birth, a child has a predisposition to engage, intersubjectively, with the rhytmic actions and awareness of other persons, and to move in synchrony with them $(44,63)$. Synchronic imitation is an important preverbal way to communicate among peers $(64,65)$. This reciprocal experience concerns two children able and motivated to coordinate their behavior with the non-ritualized behavior of the other, in both form and timing and to alternate turns between model and imitator (66). The impression of fluidity in the coordination of movements between partners is underlined by mutual attention, engagement, continuous adaptation, and turn taking (67). This rhythmic process made of ludic spontaneous imitation reveals moments of discontinuity occurring in a background of continuity. Neural bases of this coupling activity are constituted by the neuron mirrors system (68), with the same evidence showing that the neuronal structures involved when a mental state is experienced, are also recruited during the observation of others. Guionnet et al. (69) designed a free imitation paradigm in an fMRI study to examine some neural correlates of social interaction. Their results agree with those previously evidenced $(70,71)$ concerning the core circuit of imitation, but they found different activations between the situation of imitating and that of being imitated.

A special quality of temporal imitation is the ability to use different motor movements in order to communicate. Thus, simple finger tapping can be synchronized with another's head nodding or trunk movements, whether entrained by one of the movements or in response to external synchronizing stimuli such as music. Although animals and humans can perceive rhythms and produce rhythmic motor patterns, only humans can adapt their rhythmic movements to external rhythms (72) [with the exception of the cockatoo (73)]. The ability to be rhythmically synchronized with the environment appears important for infant development in the emotional, cognitive, social, and sensorimotor realms (44, 74). It has been demonstrated that the human fetus and newborn already have the capacity to perceive and produce rhythms (75). The ability to produce temporally adapted motor patterns comes later and depends on the specific motor system involved and the relationship between the beat presented and the spontaneously occurring motor tempo of the infant $(76,77)$. It should be fruitful to longitudinally examine children with autism in terms of ability to adapt their own rhythm to external rhythms. Interestingly, clinical observations suggest that some children with autism are able to respond to an external rhythmic vocalization by a similar rhythmic motor pattern such as hand flapping (Tordjman, personal communication). However, previous studies reported disorganized rhythms, stereotypies, and poor synchrony in most of these children (78), which might be related to the low melatonin levels reported to be associated in autism with the severity of verbal communication and social imitative play impairments $(18,23)$. Melatonin, as a regulator of physiological rhythms and oscillations, might enhance the capacity of children with ASD to synchronize their movements with movements of others (this synchronization of movements is needed for imitative play) and with external rhythmic auditory stimuli (such as music and/or human voice enhancing their verbal skills). Interestingly, in a study of social smiling in infants (79), there was no difference in frequency of smiling between 2- and 5-month-old infants with and without ASD during infant-caregiver face-to-face interactions. However, whereas typically developing infants showed a significant increase 
in smiling rate when caregivers were smiling, smiling in infants later diagnosed with ASD was not synchronized with smiling in caregivers and was not contingent upon caregiver behavior (caregiver facial expressions and vocalizations). Furthermore, it is noteworthy that, as previously indicated in this section, the infant's melatonin circadian rhythm is established between 2 and 3 months of age, and a study (80) reported that eye contact was normal in 2-month-old infants later diagnosed with autism but declined between 2 and 6 months of age, suggesting an additional argument in favor of a possible relationship between the wellreplicated nocturnal melatonin deficit in autism (see Table 1) and the development of autistic social communication impairments.

\section{REPETITIVE BEHAVIORS AND INTERESTS}

Repetitive behaviors and interests are defined, according to DSM5 criteria (81), as a repetition of identical sequences of behaviors for motor stereotypies (motor stereotypies involve repetitive maladaptive movements) or thoughts for restrictive patterns of interests (restrictive and repetitive interests involve fixated interests, adherence to routines, or ritualized and rigid thinking patterns). Thus, repetitive behaviors and interests can be viewed as behavioral responses to the need to create discontinuity that is repeated at regular intervals, which could have been fundamentally lacking in the physiological development of children with autism due to the melatonin deficit reported in autism. Our finding (18) observed in a sample of 43 adolescents and young adults with autism (nocturnal excretion of 6-SM was significantly negatively correlated with repetitive use of objects), taken together with improvement of stereotyped behaviors following administration of melatonin in 24 children and adolescents with ASD (82), supports this hypothesis.

The autistic deficit in melatonin secretion might lead to physiological rhythm disturbances in autism impairing biological circadian rhythms and even, in certain cases, to an "endless" physiological continuity provoked by the absence of variation in melatonin levels. From this perspective, stereotyped behaviors and interests can be seen as offering to children with autism rhythmic forms providing rhythmicity and discontinuity through the creation of repeated identical patterns. Albert Goldbeter (83), director of the Chronobiology Unit at the Brussels Sciences University, underlines that life is rhythm. It is noteworthy that the word pineal comes from pine cone that is a Mesopotamian symbol representing the source of life and the power of regeneration. In Asia, the pineal gland is considered as the 7 th chakra and represents the location of the soul and the highest level of consciousness.

Donald Winnicott (84) emphasized that "the main problem for a typically developing child is to be able to create a continuum out of discontinuity." According to him, the first optimal container ("holding environment") for the newborn is the progressive internalization of the rhythmic structures of feeding (rhythmic ebb and flow corresponding to the kinesthetic experience of suckling), providing a sense of continuing existence. We can nevertheless hypothesize, as we did in the previous section and in a prior article (26), that this internalization process starts far earlier, in the womb, through maternal physiological rhythms; conversely, based on clinical observations in autism, children with autism create discontinuity out of continuity. We can also state the hypothesis that children with autism, confronted with an "endless" physiological continuity (or at least with an absence of physiological discontinuities repeated at regular intervals), would develop anxiety and stress due to the lack of secure stable rhythms, and would therefore try to create by themselves rhythmicity in order to control them through stereotyped behaviors. However, the relationships between stereotyped behaviors and stress responses or anxiety need to be clarified given discrepant results reported in some studies $(85,86)$.

Finally, it should be noted that several studies have also recently opened new behavioral, neurobiological, and pharmacological perspectives on autistic repetitive behaviors, especially on selfinjurious behaviors [for a review, see Adler et al. (87), Minshawi et al. (88), and Stigler (89)]. Thus, research on potential therapeutic effects for repetitive behaviors and interests should investigate benefits of melatonin in ASD (see next section) but should not be limited to the administration of melatonin.

\section{THERAPEUTIC BENEFITS OF MELATONIN IN AUTISM SPECTRUM DISORDER}

Published melatonin treatment studies in autism are presented in Table 2. Many have been most concerned with effects of melatonin on sleep. Reviews, commentaries, and meta analyses of melatonin treatment studies are presented in Table 3. These two tables come from a prior article of our team (26).

As previously discussed (26), the treatment studies have a number of limitations. In some studies individuals covering a wide age range were included with pre-pubertal, pubertal, and post-pubertal individuals being studied $(102,103,105)$. Reported differences in pineal melatonin secretion according to age and pubertal stage, coupled with the clearly developmental nature of autism, suggests that therapeutic effects of melatonin might vary considerably with age and pubertal status (23). Studies have also been limited by small sample sizes (90-93, 95, 96, 98, 102, 104). In larger studies, heterogeneous groups are often examined and have included blind individuals and individuals with various neurological disabilities with concomitant intellectual disability. In such studies, often results seen for the autism subgroup are not separately presented $(97,100,103-107)$. The specificity and interpretation of the results with respect to autism are often unclear. Additional research is needed to determine whether and which findings might be specific to autism or whether melatonin's effect might be similar across groups. It can be hypothesized that melatonin's effects are due to actions on certain behavioral dimensions and that they can be observed across disorders. However, it should be pointed out that in our studies $(18,23)$, lower melatonin excretion was significantly associated with social communication impairments rather than with sleep problems. Future studies of melatonin in ASD should simultaneously examine melatonin levels, sleep problems, autistic behavioral impairments, and level of functioning so that a more complete picture can emerge.

It is worth noting that just a few of the therapeutic trials of melatonin have assessed effects on autistic behavioral impairments. These include reports of improved communication (105), reduced social withdrawal $(82,99)$, decreased stereotyped behaviors and rigidity $(82,102)$, and reduced anxiety $(99,103)$. Furthermore, at time the improvements noted were not sufficiently detailed. For example, Wright et al. (105) reported significant 
Table 2 | Studies on potential therapeutic benefits of melatonin in autism

\begin{tabular}{|c|c|c|c|c|c|c|c|c|c|c|}
\hline Study & Journal & Population & Design & $\begin{array}{l}\text { Duration of } \\
\text { treatment }\end{array}$ & $\begin{array}{l}\text { Melatonin } \\
\text { (formulation, } \\
\text { dose) }\end{array}$ & $\begin{array}{l}\text { Time of } \\
\text { intake }\end{array}$ & $\begin{array}{l}\text { Main outcome } \\
\text { measures }\end{array}$ & Effects on sleep & Other outcomes & Comments \\
\hline \multicolumn{11}{|c|}{ SINGLE CASE REPORTS } \\
\hline $\begin{array}{l}\text { Horrigan } \\
\text { and } \\
\text { Barnhill } \\
(90)\end{array}$ & $\begin{array}{l}\text { JAm Acad } \\
\text { Child } \\
\text { Adolesc } \\
\text { Psychiatry }\end{array}$ & $\begin{array}{l}\text { 17-year-old boy with } \\
\text { Asperger's Syndrome (AS) }\end{array}$ & - & Not given & $3 \mathrm{mg}$ & $\begin{array}{l}20-30 \mathrm{~min} \\
\text { before } \\
\text { bedtime (BB) }\end{array}$ & Sleep & $\begin{array}{l}\text { Sleep improvement. No } \\
\text { side effects }\end{array}$ & $\begin{array}{l}\text { Daytime behavior } \\
\text { improvement }\end{array}$ & - \\
\hline $\begin{array}{l}\text { Hayashi } \\
\text { (91) }\end{array}$ & $\begin{array}{l}\text { Psychiatry } \\
\text { Clin } \\
\text { Neurosci }\end{array}$ & $\begin{array}{l}\text { 14-year-old boy with } \\
\text { autistic disorder, severe } \\
\text { intellectual disability and } \\
\text { phase delay with } \\
\text { polyphasic sleep }\end{array}$ & - & 4 months & $\begin{array}{l}\text { Immediate release } \\
\text { (IR) } 6 \mathrm{mg}\end{array}$ & 11:00 p.m. & Sleep & $\begin{array}{l}\text { Melatonin increased sleep } \\
\text { duration. No side effects }\end{array}$ & None & - \\
\hline $\begin{array}{l}\text { Jan et al. } \\
(92)\end{array}$ & $\begin{array}{l}\text { Dev Med } \\
\text { Child Neurol }\end{array}$ & $\begin{array}{l}\text { 12-year-old boy with AS } \\
\text { and complex sleep } \\
\text { disturbance (phase delay } \\
\text { and parasomnias) }\end{array}$ & - & 6 months & $\begin{array}{l}\text { Controlled release } \\
\text { (CR) } 5 \mathrm{mg}\end{array}$ & $30 \mathrm{~min} B \mathrm{~B}$ & Sleep & $\begin{array}{l}\text { Normalization of the } \\
\text { sleep-wake rhythm and } \\
\text { disappearance of } \\
\text { parasomnias. No side } \\
\text { effects }\end{array}$ & None & - \\
\hline \multicolumn{11}{|c|}{ RETROSPECTIVE STUDIES } \\
\hline $\begin{array}{l}\text { Gupta and } \\
\text { Hutchins } \\
\text { (93) }\end{array}$ & $\begin{array}{l}\text { Arch Dis } \\
\text { Child }\end{array}$ & $\begin{array}{l}9 \text { cases of children with } \\
\text { autistic disorder (AD) } \\
\text { aged from } 2 \text { to } 11 \text { years. } \\
\text { Chronic sleep problems }\end{array}$ & Not given & $\begin{array}{l}1 \text { week to } \\
1 \text { year }\end{array}$ & IR 2.5-5 mg & $45 \mathrm{~min} B \mathrm{~B}$ & $\begin{array}{l}\text { Parental evaluation of } \\
\text { sleep }\end{array}$ & $\begin{array}{l}56 \% \text { showed } \\
\text { improvement in total } \\
\text { sleep duration }\end{array}$ & None & $\begin{array}{l}\text { No standardized collection } \\
\text { of sleep variables }\end{array}$ \\
\hline $\begin{array}{l}\text { Andersen } \\
\text { et al. (94) }\end{array}$ & $\begin{array}{l}J \text { Child } \\
\text { Neurol }\end{array}$ & $\begin{array}{l}107 \text { children and } \\
\text { adolescents aged from } 2 \\
\text { to } 18 \text { years with ASD } \\
\text { (DSM-IV): } 71 \% \text { AD, } 5 \% \\
\text { AS, } 19 \% \text { PDDNOS } \\
\text { (pervasive developmental } \\
\text { disorder not otherwise } \\
\text { specified) }\end{array}$ & Not given & $\begin{array}{l}\text { Mean } \\
\text { duration: } \\
1.8 \text { years }\end{array}$ & $\begin{array}{l}\text { IR in } 91 \% \text { of the } \\
\text { cases. Dose } \\
\text { escalation protocol } \\
\text { from } 1 \text { to } 6 \mathrm{mg} \\
\text { based upon age }\end{array}$ & $\begin{array}{l}30-60 \\
\min B B\end{array}$ & $\begin{array}{l}\text { Parental evaluation of } \\
\text { sleep }\end{array}$ & $\begin{array}{l}\text { Parents reported full } \\
(25 \%) \text { or partial }(60 \%) \\
\text { improvement. Beneficial } \\
\text { effects of melatonin seem } \\
\text { to stop after } 3-12 \text { months } \\
\text { despite the use of higher } \\
\text { doses. Side effects } \\
\text { observed in } 3 \text { children: } \\
\text { sleepiness, fogginess, } \\
\text { increased enuresis }\end{array}$ & None & $\begin{array}{l}\text { No standardized collection } \\
\text { of sleep variables. The } \\
\text { loss of response to } \\
\text { melatonin treatment is } \\
\text { discussed in the text }\end{array}$ \\
\hline $\begin{array}{l}\text { Galli- } \\
\text { Carminatti } \\
\text { et al. (95) }\end{array}$ & $\begin{array}{l}\text { Swiss Med } \\
\text { Wkly }\end{array}$ & $\begin{array}{l}6 \text { adult patients with } A D \\
\text { (CIM-10) and intellectual } \\
\text { disability, aged from } 19 \text { to } \\
52 \text { years }\end{array}$ & Not given & 6 months & $\begin{array}{l}\text { IR. Dose escalation } \\
\text { protocol from } 3 \text { to } \\
9 \mathrm{mg} \text { if clinically } \\
\text { required }\end{array}$ & $45 \min B B$ & $\begin{array}{l}\text { Sleep (CGI-S and } \\
\text { CGI-I) }\end{array}$ & $\begin{array}{l}\text { Improvement in sleep } \\
\text { onset latency, night and } \\
\text { early morning } \\
\text { awakenings. No side } \\
\text { effects }\end{array}$ & None & $\begin{array}{l}\text { No standardized collection } \\
\text { of sleep variables. Two to } \\
\text { four associated } \\
\text { psychotropic drugs per } \\
\text { patient }\end{array}$ \\
\hline \multicolumn{11}{|c|}{ OPEN-LABELTRIALS } \\
\hline $\begin{array}{l}\text { Jan et al. } \\
\text { (96) }\end{array}$ & $\begin{array}{l}\text { Dev Med } \\
\text { Child Neurol }\end{array}$ & $\begin{array}{l}15 \text { children with multiple } \\
\text { neurological disabilities } \\
\text { and severe sleep } \\
\text { disorders }\end{array}$ & Not given & Not given & $2-10 \mathrm{mg}$ & Bedtime & Not given & $\begin{array}{l}\text { Partial improvement in } \\
\text { sleep disorders. No side } \\
\text { effects }\end{array}$ & $\begin{array}{l}\text { Behavior and social } \\
\text { improvement }\end{array}$ & $\begin{array}{l}\text { Heterogeneous sleep } \\
\text { disorders and neurological } \\
\text { disabilities }\end{array}$ \\
\hline $\begin{array}{l}\text { Ishizaki } \\
\text { et al. (97) }\end{array}$ & $\begin{array}{l}\text { No To } \\
\text { Hattatsu }\end{array}$ & $\begin{array}{l}50 \text { children and young } \\
\text { adults with autism } \\
(n=27) \text { or mental } \\
\text { retardation }(n=20) \text { or } \\
\text { severe motor/intellectual } \\
\text { disability }(n=3) \text { aged } \\
\text { from } 3 \text { to } 28 \text { years with } \\
\text { sleep disorders }\end{array}$ & Not given & Not given & Not given & Not given & $\begin{array}{l}\text { Sleep disorders and } \\
\text { emotional/behavior } \\
\text { disturbances }\end{array}$ & $\begin{array}{l}34 \text { patients experienced } \\
\text { improvement in response } \\
\text { to melatonin. Side effects } \\
\text { reported in } 17 \text { patients }\end{array}$ & $\begin{array}{l}\text { Improvements in } \\
\text { excitability when sleep } \\
\text { also improved. No change } \\
\text { in contrariness, } \\
\text { stereotyped behavior and } \\
\text { in school/workshop } \\
\text { refusal }\end{array}$ & $\begin{array}{l}\text { Various types of insomnia } \\
\text { and diagnoses }\end{array}$ \\
\hline
\end{tabular}


Table 2 | Continued

\begin{tabular}{|c|c|c|c|c|c|c|c|c|c|c|}
\hline Study & Journal & Population & Design & $\begin{array}{l}\text { Duration of } \\
\text { treatment }\end{array}$ & $\begin{array}{l}\text { Melatonin } \\
\text { (formulation, } \\
\text { dose) }\end{array}$ & $\begin{array}{l}\text { Time of } \\
\text { intake }\end{array}$ & $\begin{array}{l}\text { Main outcome } \\
\text { measures }\end{array}$ & Effects on sleep & Other outcomes & Comments \\
\hline $\begin{array}{l}\text { Paavonen } \\
\text { et al. (98) }\end{array}$ & $\begin{array}{l}\text { J Child } \\
\text { Adolesc } \\
\text { Psychophar- } \\
\text { macol }\end{array}$ & $\begin{array}{l}15 \text { children with AS } \\
\text { (DSM-IV) aged from } 6 \text { to } \\
17 \text { years with severe } \\
\text { sleep problems for at } \\
\text { least } 3 \text { months }\end{array}$ & Not given & 14 days & IR $3 \mathrm{mg}$ & $30 \mathrm{~min} B B$ & $\begin{array}{l}\text { Sleep (72 h-period } \\
\text { actigraphy, sleep } \\
\text { diaries), daytime } \\
\text { behavior (Karolina } \\
\text { Sleepiness Scale; } \\
\text { KSS), Child Behavior } \\
\text { Checklist (CBCL) }\end{array}$ & $\begin{array}{l}\text { Melatonin treatment was } \\
\text { associated with significant } \\
\text { decrease in sleep onset } \\
\text { latency and nocturnal } \\
\text { activity. Discontinuation of } \\
\text { melatonin led to a } \\
\text { significant decrease in } \\
\text { sleep duration and more } \\
\text { nocturnal activity. Side } \\
\text { effects in } 20 \% \text { of the } \\
\text { cases: tiredness, } \\
\text { headaches, severe } \\
\text { sleepiness, dizziness, } \\
\text { diarrhea }\end{array}$ & $\begin{array}{l}\text { Significant improvement } \\
\text { of daytime behavior } \\
\text { (CBCL) }\end{array}$ & $\begin{array}{l}\text { No principal outcome } \\
\text { specified. KSS is not } \\
\text { validated in children nor } \\
\text { in ASD }\end{array}$ \\
\hline $\begin{array}{l}\text { Giannotti } \\
\text { et al. (99) }\end{array}$ & $\begin{array}{l}\text { J Autism } \\
\text { Dev Disord }\end{array}$ & $\begin{array}{l}29 \text { children with AD } \\
\text { (DSM-IV) aged from } 2 \text { to } \\
9 \text { years with current sleep } \\
\text { problems }\end{array}$ & $\begin{array}{l}\text { Controlled-release } \\
\text { melatonin }\end{array}$ & 6 months & $\begin{array}{l}\text { Dose escalation } \\
\text { protocol from } 3 \mathrm{mg} \\
(1 \mathrm{mg} \text { of } I \mathrm{R}+2 \mathrm{mg} \\
\text { of CR) to } 6 \mathrm{mg} \text { when } \\
\text { clinically required, } \\
\text { based upon age } \\
\text { (max } 4 \mathrm{mg} \text { under } \\
4 \text { years old and max } \\
6 \mathrm{mg} \text { over } 6 \text { years } \\
\text { old) }\end{array}$ & 08:00 p.m. & $\begin{array}{l}\text { Sleep (diaries and } \\
\text { Children's Sleep } \\
\text { Habits Questionnaire } \\
\text { CSHQ), daytime } \\
\text { behavior, Childhood } \\
\text { Autism Rating Scale } \\
\text { (CARS) }\end{array}$ & $\begin{array}{l}\text { Melatonin treatment was } \\
\text { associated with } \\
\text { improvement in sleep } \\
\text { onset latency, night } \\
\text { awakenings, and sleep } \\
\text { duration, which vanished } \\
\text { after melatonin } \\
\text { discontinuation. No side } \\
\text { effects }\end{array}$ & $\begin{array}{l}\text { Parents reported less } \\
\text { irritability, less anxiety, } \\
\text { and better mood. } \\
\text { Significant improvement } \\
\text { of depression, anxiety, } \\
\text { and withdrawal symptoms } \\
\text { during melatonin } \\
\text { treatment in children with } \\
\text { AS. No effect was } \\
\text { reported on the CARS }\end{array}$ & $\begin{array}{l}\text { No principal outcome } \\
\text { specified. Missing data: } \\
\text { analyses on } 25 \text { patients }\end{array}$ \\
\hline $\begin{array}{l}\text { De } \\
\text { Leersnyder } \\
\text { et al. (100) }\end{array}$ & $\begin{array}{l}\text { Pediatr } \\
\text { Neurol }\end{array}$ & $\begin{array}{l}88 \text { children with } \\
\text { heterogeneous } \\
\text { neurodevelopmental } \\
\text { disorders (Smith-Magenis } \\
\text { syndrome, mental } \\
\text { retardation, } \\
\text { encephalopathy, } \\
\text { Angelman syndrome, Rett } \\
\text { syndrome, Bourneville } \\
\text { syndrome, blindness, and } \\
\text { autism) aged from } 5 \text { to } \\
20 \text { years. Seven patients } \\
\text { with autism, mean age } \\
12 \text { years old }\end{array}$ & $\begin{array}{l}6 \text { years of open-label } \\
\text { follow up }\end{array}$ & 3 months & $\begin{array}{l}\text { CR } 2-4 \mathrm{mg}(<40 \mathrm{~kg}) \\
\text { or } 6 \mathrm{mg}(>40 \mathrm{~kg}) \\
\text { based upon weight }\end{array}$ & $60 \min B B$ & $\begin{array}{l}\text { Parental evaluation of } \\
\text { sleep and mood } \\
\text { (self-constructed } \\
\text { questionnaire) }\end{array}$ & $\begin{array}{l}\text { According to parental } \\
\text { reports, both sleep } \\
\text { latency and sleep duration } \\
\text { improved within } 3 \text { months } \\
\text { such as night awakenings, } \\
\text { sleep quality, and daytime } \\
\text { napping. Eleven children } \\
\text { experienced adverse } \\
\text { events (daytime nap, } \\
\text { difficulties in swallowing } \\
\text { tablets) that the parents } \\
\text { attributed to melatonin } \\
\text { treatment }\end{array}$ & $\begin{array}{l}12 \% \text { of the parents } \\
\text { reported improvements of } \\
\text { mood in their children }\end{array}$ & $\begin{array}{l}\text { Heterogeneous } \\
\text { neurodevelopmental } \\
\text { disorders. Results cannot } \\
\text { apply to a population with } \\
\text { autism spectrum } \\
\text { disorders. No } \\
\text { standardized collection of } \\
\text { sleep and mood } \\
\text { parameters. Mean dose } \\
\text { for patients with autism: } \\
5.7 \mathrm{mg}\end{array}$ \\
\hline $\begin{array}{l}\text { Malow } \\
\text { et al. (82) }\end{array}$ & $\begin{array}{l}\text { J Autism } \\
\text { Dev Disord }\end{array}$ & $\begin{array}{l}24 \text { children with ASD } \\
\text { (DSM-IV, ADOS): AD, AS, } \\
\text { and PDDNOS aged from } 3 \\
\text { to } 9 \text { years. Sleep onset } \\
\text { delay of } 30 \text { min or longer } \\
\text { confirmed on actigraphy. } \\
\text { Exclusion of } \\
\text { neurodevelopmental } \\
\text { disabilities such as fragile } \\
\text { X, Down, and Rett } \\
\text { syndromes }\end{array}$ & $\begin{array}{l}\text { Before treatment } \\
\text { families received } \\
\text { structured sleep } \\
\text { education and } \\
\text { children underwent } \\
\text { a treatment } \\
\text { acclimatation phase } \\
\text { in order to be sure } \\
\text { the melatonin will } \\
\text { be taken }\end{array}$ & 14 weeks & $\begin{array}{l}\text { CR. Dose escalation } \\
\text { protocol from } 2 \text { to } \\
9 \mathrm{mg} \text { when clinically } \\
\text { required }\end{array}$ & $30 \mathrm{~min} B B$ & $\begin{array}{l}\text { Sleep (actigraphy, } \\
\text { Children's Sleep } \\
\text { Habits Questionnaire; } \\
\text { CSHQ, diaries), } \\
\text { daytime behavior } \\
\text { (Child Behavior } \\
\text { Checklist; CBCL, } \\
\text { Repetitive Behavior } \\
\text { Scale-Revised), } \\
\text { parental stress } \\
\text { (Parenting Stress } \\
\text { Index Short Form), } \\
\text { side effects (Hague } \\
\text { Side Effects Scale) }\end{array}$ & $\begin{array}{l}\text { Significant improvement } \\
\text { in sleep latency within the } \\
\text { first week of treatment } \\
\text { but not for other sleep } \\
\text { parameters such as night } \\
\text { awakenings and sleep } \\
\text { quality }\end{array}$ & $\begin{array}{l}\text { Significant improvement } \\
\text { in children's behavior } \\
\text { (withdrawal, affective } \\
\text { problems, attention-deficit } \\
\text { hyperactivity, } \\
\text { stereotyped, and } \\
\text { compulsive behaviors). } \\
\text { Significant improvement } \\
\text { in parental stress }\end{array}$ & No placebo \\
\hline
\end{tabular}


Study Journal

Population

Design

Duration of Melatonin

Time of

Main outcome

Effects on sleep

dose)

\section{PLACEBO-CONTROLLED TRIAL}

PLACEBO-CONTRO

McArthur DevMed 9 children and

Randomized

2 periods $\quad 25-75 \mathrm{mg}$ based on $\quad 60 \mathrm{~min} B$

Sleep lactigraphy,

Significant improvement None

(101)

$2.5-7.5$
weight

diaries)

17 years. Me
age: 10 years old

with a

side effects

period of

1 week

$\begin{array}{ll}\text { Garstang } & \text { Child Care } \\ \text { and Wallis } & \text { Health Dev }\end{array}$

(102)

11 children and

adolescents with ASD

Randomized

2 periods

IR $5 \mathrm{mg}$

double-blind

2 periods

IR $5 \mathrm{mg}$

60 min BB Sleep (diary)

Melatonin and placebo

with chronic sleep

with a

behavioral treatment

wash out

1 week

were associated with

sleep latency and

Several parents and class ASD criteria were not

teachers commented that consensual. Only 7

their children were easier children completed the

nocturnal

to manage and less rigid

rial. Investigators found

increased total sleep

avior while

that some of the placebo

time. No side effects

Missing data

Wasdel

51 children and

Randomized 2 periods

adolescents with

2 periods

Dose escalation

20-30 Sleep (actigraphy,

Significant improvement

et al. (103) neurc

disabilities (16 patients

with ASD) aged from 2 to

crossover trial. Three with a

protocol based o

Half of the patients with Unspecified ASD criteria. weeks trial followed wash out conditions: from

familial stress (family sleep latency as well as.

reduced stress levels in

18 years. Sleep delay 2

a 3-month period of

conditions:

reduced stress levels in

the trial and 47 completed

phase syndrome and

open-label study

3-5 days $\quad \mathrm{FR}+4 \mathrm{mg} \mathrm{CR})$ to

arm

open-label phase with no the open-label phase.

additional improvement in Selection bias due to

sleep latency or sleep previous melatonin

duration, but caregivers treatment $(25 \%$ of the

trial, 29 patients received

a dose of 10 or $15 \mathrm{mg}$

Higher doses were

necessary in patients with

bilateral cerebral lesions

resistant to sleep hygien

inclusion

Wirojan

12 children and

Randomized

dolescents with double-blind

2 periods $\quad \mathrm{IR} 3 \mathrm{mg}$

diary)

Significant, but mild

improvement in total

patients completed the

trial (order bias). No

problems, aged from 2 to

No wash

sleep time $(+21 \mathrm{~min})$ and

5 years: 5 patients with

(ADOS and ADI-R),

3 patients with fragile $X$
syndrome with $A D$,

3 patients with $A D$ and

fragile $X$ syndrome, and

1 patient with fragile $X$

premutation

$\begin{array}{ll}\text { Wright } & \text { J Autism } \\ \text { et al. (105) } & \text { Dev Disord }\end{array}$

22 children and

dolescents aged from

Randomized

out period

(-28 min)

subgroup analysis in $A D$

patients. No side effects

(ICD-10, ADOS, ADI-R):

2 periods IR. Dose escalation $\quad 30-40$

of 3 months protocol from 2

$\min B B$

Sleep (sleep
difficulties

questionnaire, diary)

in sleep latency $(-47 \mathrm{~min})$

by 1 month clinically required

daytime behavior

$(+52 \mathrm{~min})$ in the duration

Behavior Checklist

AA $(20 \%)$. No fragile X or

Behavior Checkls
side effect

arm. No improvement in

the melatonin

side efrect

side effect profile. The

significantly different.

sleeplessness (confirmed

between the 2 groups

on a 1-month-diary) and

treatment 


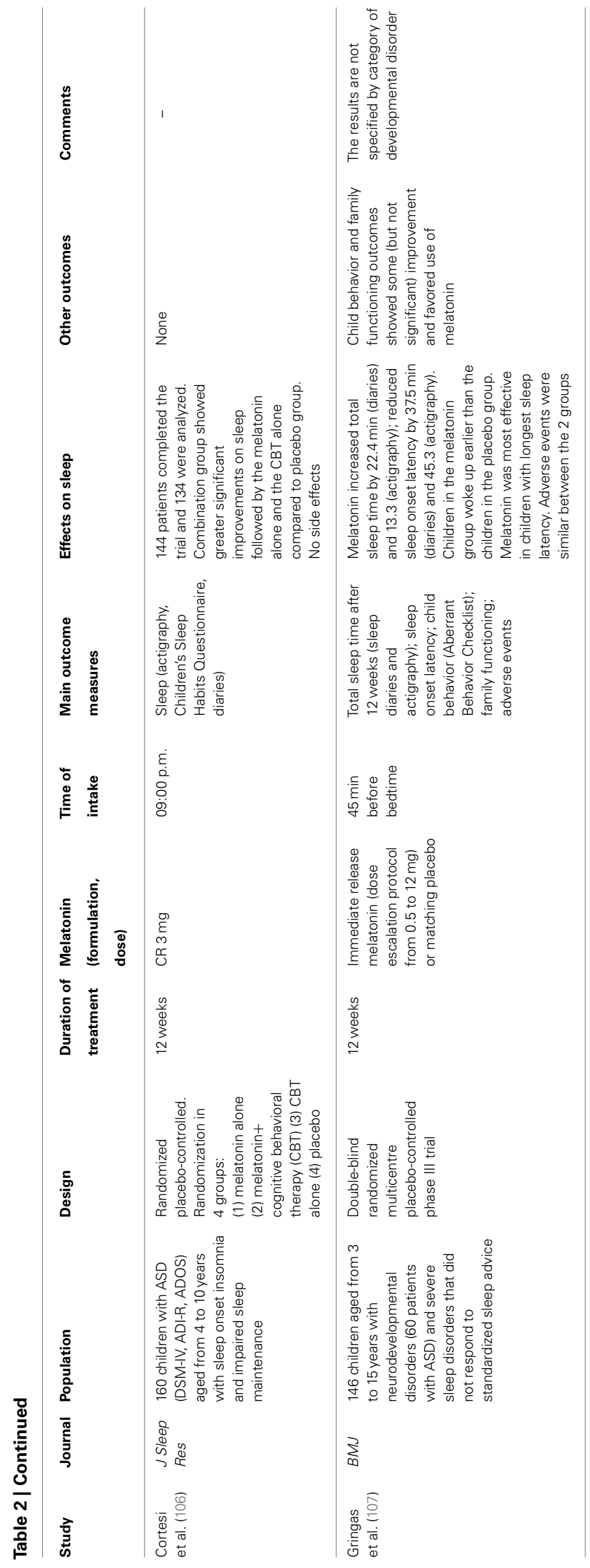

communication improvement without reporting separate verbal or non-verbal scores. In other instances, investigators did not use validated instruments; thus, Garstang and Wallis (102) reported improvements in rigidity based solely on parents' and teachers' comments, while Wasdell et al. (103) reported reductions in anxiety based on caregivers' comments. All of the published clinical trials of melatonin in autism/ASD have used sleep measures as their main outcome variable and none have studied the doseresponse relationship for melatonin. To reiterate, there is a real need for further studies on the therapeutic effects of melatonin that are conducted on large, relatively homogeneous samples and that employ validated behavioral assessments.

\section{SYNCHRONIZATION OF MOTOR, EMOTIONAL, AND RELATIONAL RHYTHMS: THERAPEUTIC BENEFITS OF THE EARLY START DENVER MODEL IN AUTISM SPECTRUM DISORDER}

Although there is a growing interest in the role of motor, emotional, and interpersonal rhythms in autism, there have been only a few attempts to focus on behavioral synchronization of social communication during therapeutic and educational intervention in autism. The ESDM, developed by Sally Rogers and Geraldine Dawson $(119,120)$, is a comprehensive behavioral and developmental early intervention approach designed for delivery to 12- to 60-month-old children. The model uses the knowledge of how typical infants, toddlers, and pre-schoolers develop, in addition to knowledge of the ways in which autism affects early development, in order to facilitate an appropriate developmental trajectory in young children with autism beginning at the earliest ages. The goals of the ESDM are to reduce the severity of disabling autism symptoms in very young children, and to accelerate children's developmental rates in a multitude of domains, including cognitive, social-emotional, and language domains. In order to do so, there is a strong focus on interpersonal engagement marked by synchrony and reciprocity during teaching, as research demonstrates that these are closely tied to successful developmental outcomes (121-124). Within the ESDM, the therapist and child work together to develop and sustain coordinated, synchronous activity routines into which teaching opportunities are embedded. The ESDM reflects an understanding of the importance of synchrony of motor, emotional, and relational rhythms for the early development of young children with autism.

Thus, the ESDM allows one to initiate interaction with the child by synchronizing the therapist's motor, emotional, and relational rhythms with the child's rhythms (providing invariants/continuity). For example, if the child uses an object with a rhythmic motor pattern, the therapist will reproduce this behavior with exactly the same rhythmic pattern. The evolution of the child is then facilitated by introducing new and different rhythms (providing variants/discontinuity). In addition, the adjustment of the therapist's behaviors, movements, level of arousal, and posture (for example, standing up, lying down, or sitting) to those of the child contributes to foundational invariants necessary during the initial phase. Furthermore, the ESDM requires the program to be implemented in different environments (such as home, school, and caregiver settings), which also contributes to the introduction of variants. 
Table 3 | Review, meta-analysis, and discussion of therapeutic uses of melatonin in autism.

\section{REVIEW/META-ANALYSIS}

Jan and

$J$ Pineal Res

O’Donnel (108)

Jan et al. (109)

Dev Med Child

Neurol

Phillips and

Appleton (110)

Dev Med Child

Braam et al. (111)

Neurol

Dev Med Child

Neurol

Guénolé

et al. (112)

Doyen et al. (113)

Psychiatry

Rossignol and

Frye (114)

Reading (115)

Sleep Med Rev

$$
\text { Psychiatry }
$$

Dev Med Child Neurol
Eur Child Adolesc

(n)
PDDNOS, and Rett syndrome. Effectiveness on sleep disorders was found in all the studies, side effects were reported in 5 studies. Melatonin doses ranged from 0.5 to $10 \mathrm{mg}$. Melatonin seems to have anxiolytic properties. Most frequent reported side effects: infections, flu, epilepsy, intestinal disorders, and agitation

Child Care Health Dev

Systematic review of efficacy and safety of exogenous melatonin for treating disordered sleep in individuals with autism spectrum disorders: 4 case reports, 3 retrospective studies, 2 open-label clinical trials, 3 placebo-controlled trials. All studies supported the existence of a beneficial effect of melatonin on sleep in individuals with ASD with minor side effects. Limitations are: small sample, clinical heterogeneity of ASD and sleep disorders, varying methods used to measure sleep, confounding factors such as behavioral interventions and cross over design (no analysis of intention to treat). Melatonin doses ranged from 0.75 to $10 \mathrm{mg} / \mathrm{day}$. The authors propose that future research on the efficacy of melatonin in children with ASD should include daytime functioning as a principal outcome measure. Only 6 patients of 205 presented side effects: daytime sleepiness, fogginess, dizziness, nocturnal enuresis, tiredness, headache, and diarrhea

Systematic review on pharmacokinetics data on melatonin and its role in sleep disorders and autism spectrum disorders. Authors reviewed 17 studies on effectiveness and side effects of melatonin in patients with AD, AS,

Aim of the study: investigate melatonin-related findings in ASD including AD, AS, Rett syndrome, and PDDNOS. Eighteen studies on melatonin treatment on ASD patients were identified (5 RCT), 12 of them reported improvement in sleep with melatonin in $67 \%$ to $100 \%$ of the patients. Six studies reported improvement in daytime behavior (less behavioral rigidity, ease of management for parents and teachers, better social interaction, fewer temper tantrums, less irritability, more playfulness, better academic performance, and increased alertness). Melatonin doses ranged from 0.75 to $15 \mathrm{mg}$, age of patients ranged from 2 to 18 years, treatment duration ranged from 2 weeks to 4 years. Twelve studies explored side effects (headache, tiredness, dizziness, and diarrhea) in which 7 studies reported no side effects. Nine studies found low levels or abnormal circadian rhythm of melatonin in ASD. A correlation between these abnormal levels and autistic behaviors was found in 4 studies. Night time urinary excretion of melatonin metabolite (6-SM) was reported to be inversely correlated with the severity of impairments in verbal communication, play, and daytime sleepiness in patients with ASD. Five studies found genetic abnormalities of melatonin receptor and enzymes involved in melatonin synthesis

Correlation between plasmatic levels of melatonin and autistic behaviors was found. Melatonin groups showed improvements in total sleep duration and sleep onset latency versus placebo groups but not on night
Review based on 100 individuals with chronic sleep disorders, aged from 3 months to 21 years. Half of these 100 patients presented visual impairment or blindness. Melatonin dose ranged from 2.5 to $10 \mathrm{mg}$. Higher doses were needed in patients with impaired sleep maintenance. Partial or total improvement in sleep parameters was found in $82 \%$ of the cases. No side effects

Systematic review of studies on melatonin in children. Twenty-four studies found, most of them were case reports or uncontrolled studies with small samples. Mean age: 10 years old. Associated diagnosis: blindness and neurodevelopmental disabilities, 1 single case of an adolescent with AS (76). Doses ranged from 0.5 to $20 \mathrm{mg}$. Improvement in sleep in all the studies

Only three studies, reporting a total of 35 children, fulfilled the criteria for inclusion (randomized controlled clinical trials). Two of them reported a significant decrease in time to sleep onset

Meta-analysis of placebo-controlled randomized trials of melatonin in individuals with intellectual disabilities and sleep problems. Nine studies were included. Various doses and formulations of melatonin were given. Melatonin decreased sleep latency by a mean of $34 \mathrm{~min}(p<0.001)$, significantly decreased mean number of wakes per night $(p=0.024)$, and increased total sleep time by $50 \mathrm{~min}(p<0.001)$. Specified reports on adverse effects were given in four studies. Adverse effects were minor and their incidence in both melatonin and placebo phases were the same. Patient groups in studies included in this meta-analysis were very heterogeneous awakenings 
Table 3 | Continued

\begin{tabular}{|c|c|c|}
\hline \multicolumn{3}{|c|}{ LETTER TO THE EDITOR } \\
\hline $\begin{array}{l}\text { Guénolé and } \\
\text { Baleyte (116) }\end{array}$ & $\begin{array}{l}\text { Dev Med Child } \\
\text { Neurol }\end{array}$ & $\begin{array}{l}\text { Response to the Rossignol and Frye review (73); Authors proposed that studies should separately explore sleep } \\
\text { disorders in patients with ASD and sleep disorders in patients with Rett syndrome }\end{array}$ \\
\hline $\begin{array}{l}\text { Guénolé and } \\
\text { Baleyte (117) }\end{array}$ & Pediatr Neurol & $\begin{array}{l}\text { Response to the De Leersnyder et al. study (86) of open-label trial. The definition of «chronic sleep disorder»did } \\
\text { not refer to international classifications. Half of the children manifested Smith-Magenis syndrome that involves } \\
\text { specific abnormalities of melatonin secretion. Thus, results cannot apply to a population with ASD. The effects of } \\
\text { melatonin should be studied separately in each neurodevelopmental disorder and with specific sleep diagnoses }\end{array}$ \\
\hline \multicolumn{3}{|c|}{ DISCUSSION/COMMENTARY } \\
\hline $\begin{array}{l}\text { Jan and } \\
\text { Freeman (92) }\end{array}$ & $\begin{array}{l}\text { Dev Med Child } \\
\text { Neurol }\end{array}$ & $\begin{array}{l}\text { Discussion on melatonin use in children with ADHD, ASD, neurodevelopmental disabilities, epilepsy, and } \\
\text { blindness. Exogenous melatonin seems to regulate endogenous melatonin secretion. It seems to be more } \\
\text { effective in sleep-wake cycle disorders with sleep onset delay disorders. Night and morning awakenings seem } \\
\text { to be more difficult to treat, such as sleep problems associated with cerebral lesions. The more the child shows } \\
\text { mental or motor comorbidities, the more the melatonin dose is high }\end{array}$ \\
\hline
\end{tabular}

Lord (118) J Autism Dev General brief discussion of melatonin and its potential for treating sleep problems in autism

Disord

The ESDM is both a curriculum and a set of teaching practices. A specific developmental curriculum, administered every 3 months in typical practice, defines the skills to be taught at any given time. In addition, a manual of teaching practices outlines the ways in which these skills are to be taught. Embedded within both the curriculum and the set of teaching practices is a focus on rhythms and synchrony. In other words, when therapists are working within the model, a focus on rhythms permeates both what they teach and how they teach it.

The ESDM curriculum outlines skills to be taught in multiple areas, including cognitive, social-emotional, and language domains. The curriculum focuses heavily upon the teaching of skills that promote engagement with other people in a synchronous, rhythmic way. Many young children with autism enter an ESDM program with weaknesses in these skills, such as imitation, joint attention, orienting to name, and eye contact, and these have broad influences upon the manner in which these children can engage with others. It is well recognized that learning occurs within a social context and that social skills, such as imitation and shared attention, provide a foundation for many aspects of learning, including language, cognitive, and social-emotional abilities. Thus, the ESDM focuses heavily on the development of social engagement and interactional synchrony early on in order to further support learning of a wide range of skills.

One area of focus within the ESDM, which is closely tied to the concept of rhythmicity, is imitation. Young children with autism often exhibit deficits in their imitation skills, including those of imitating others' facial expressions and movements, gestures, body actions, and actions on objects. From the beginning of a young child's ESDM program, teaching of imitation is stressed, from basic imitation of actions on objects to more nuanced imitation of sound effects produced in play. Spontaneous and appropriate imitation of others is typically rhythmic and marked by mutual attention, continuous adaptation, and turn taking. The beginning stages of facilitating imitation and social engagement often start with imitating the child, thereby entering into a rhythmic interaction with the child. By imitating the child's movements and establishing a synchronous interaction, eye contact and mutual engagement in the interaction are promoted (125).

Rhythmicity is also involved in the way teaching occurs within the ESDM upon multiple levels, from the basic structure of each interactive routine to the ways in which adults engage with children during interaction. Social communication is about sharing moments of synchrony with others, and the ESDM supports the emergence of interactional synchrony. The therapist facilitates the occurrence of synchronous moments and strings them together into routines into which the therapist can naturally embed teaching opportunities. The primary vehicle through which all teaching is accomplished in this model is the joint activity routine, which is permeated by moments of rhythmic, synchronous interaction, and enriched with positive affect. Adult and child are attuned to one another, both taking the lead, both following the other's lead, taking turns, and creating a positive and motivating activity in conjunction with one another.

The joint activity routine, although flexible and naturalistic, adheres to a four-part structure: (1) opening, (2) theme, (3) elaboration, and (4) closing. This structure provides a set of invariants, against which multiple variants can occur at differing levels. In order to begin engagement within a joint activity routine, the adult works hard to find the child's smile. This can often be accomplished by getting into the child's own rhythm (imitating a child's actions is a very powerful tool to facilitate motivated response and interaction) or by finding a rhythm that the child likes. For example, perhaps a child finds a toy drum and begins banging on it with his hand. In the ESDM, the therapist would join the child and would likely take her/his own drum and imitate the child's actions, joining his rhythm. This would be considered the opening phase of the joint activity routine.

Next, the child and adult would develop a theme. This can be considered a continuation of the rhythm introduced during the 
opening phase - in our example, banging a drum slowly with hands. The adult and child would take turns doing so, each leading and each following. The skillful adult would embed teaching opportunities into these turns - perhaps a focus on eye contact during dyadic engagement, or on imitation of actions on objects, or on giving and taking objects with eye contact. Both partners then play within this rhythm for a while, until one introduces a variant, or elaboration. In the ESDM, elaboration occurs by introducing a change into the joint activity routine, a change in the rhythm which often allows different teaching targets to be practiced. In this example, the child and adult might start to play peek-a-boo behind the drums. A new rhythm would need to be established, and both partners would work together in order to do so. An elaboration of this sort is a rhythmic fluctuation occurring against a background of invariants (e.g., the same interactive partner, the same material, the same setting), which allows the child to learn to adapt to change and teaches the child how to engage with people and materials differently. Finally, this rhythm would likely begin to fade, the teaching value of the activity would start to diminish, and/or the child would begin to lose motivation. The fourth stage of the joint activity routine - the closing - is the last part of the joint activity routine. Adult and child might help one another clean up the materials, and then both partners would begin an entirely new joint activity routine. This could often involve a change in location, activity level, or teaching domain, and an entirely new set of coordinated interactions would be developed.

Within the joint activity routine, synchrony pervades within several different levels and in several different areas. Adult and child are attuned to one another and responsive to one another in terms of sensory input and output, motor actions, and emotions. Coordinated dyadic engagement, well-balanced in terms of leader and follower, pervades a high-quality joint activity routine. It is quite natural to view this ever-present synchrony in terms of a focus on shared nuanced rhythms.

There is also a focus on rhythmicity within some of the broader teaching practices of the ESDM; for example, in the way in which a teaching session is constructed. As mentioned above, teaching is delivered within joint activity routines. For a therapist-delivered session, these routines are strung together within a session to occupy a full 1 - or 2 -h time period. Within that time period, therapist and child move around to occupy several spaces. In a well-coordinated way, they engage together in a joint activity routine at the table, and then may move onto the floor for the next. They may sit together, then they may stand or walk or run. The child's level of arousal is carefully monitored, and the session is marked by alternations of quiet thoughtfulness and active play, all coordinated artfully by a skilled adult. All of these changes occur against a stable background, as the session is marked by stability and continuity, with the introduction of variants when appropriate. The ESDM, a comprehensive, behavioral, and developmental early intervention designed for infants and toddlers with autism, is rooted within a sense of and appreciation for rhythmicity and synchrony at multiple levels, ranging from the specific skills that are taught to how those skills are taught, woven together and supported by a broader structure focused on maintaining a well-coordinated, synchronous set of dyadic interactions.

\section{CONCLUSION: TOWARD AN INTEGRATIVE APPROACH} COMBINING THE USE OF MELATONIN WITH THE ESDM

Taken all together, ASD could be seen as a disorder of rhythmicity with, more specifically, impairments in the synchrony of rhythms. Alternatively, such asynchrony might play an important role in a possibly large subgroup of individuals that forms part of the heterogeneous ASD category. In this article, we proposed an integrative approach to study desynchronization in biological and psychological rhythms in ASD and develop an etiopathogenic hypothesis as well as therapeutic perspectives for ASD based on this integrative approach. Indeed, this integrated physiological and psychological approach opens important therapeutic perspectives for ASD based on regulation of physiological rhythms (in particular, through the use of chronobiotics such as melatonin, and also through light exposure, use of regularly scheduled bedtime, wake up, meals, or activities) combined with synchronization of motor, emotional, and relational rhythms through developmental behavioral intervention such as the ESDM. Further studies are required to better ascertain the underlying mechanisms of physiological alterations induced by temporal desynchronization and to better understand the role of biological rhythms and rhythmicity in the development of social communication, repetitive behaviors, and interests or adaptation to changes, and therefore in the development of autism involving impairments in these domains.

\section{REFERENCES}

1. Pevet P, Challet E. Melatonin: both master clock output and internal timegiver in the circadian clocks network. J Physiol Paris (2011) 105:170-82. doi:10.1016/j.jphysparis.2011.07.001

2. Botbol M, Cabon P, Kermarrec S, Tordjman S. Biological and psychological rhythms: an integrative approach to rhythm disturbances in autistic disorder J Physiol Paris (2013) 107(4):298-309. doi:10.1016/j.jphysparis.2013.03.009

3. Molenaar PCM, Campbell CG. The new person-specific paradigm in psychology. Curr Dir Psychol Sci (2009) 18(2):112-7. doi:10.1111/j.1467-8721.2009. 01619.x

4. Glickman G. Circadian rhythms and sleep in children with autism. Neurosci Biobehav Rev (2010) 34(5):755-68. doi:10.1016/j.neubiorev.2009.11.017

5. Kotagal S, Broomall E. Sleep in children with autism spectrum disorder. J Pediatr Neurol (2012) 47(4):242-51. doi:10.1016/j.pediatrneurol.2012.05.007

6. Honomichl RD, Goodlin-Jones BL, Burnham M, Gaylor E, Anders T. Sleep patterns of children with pervasive developmental disorders. J Autism Dev Disord (2002) 32:553-61. doi:10.1023/A:1021254914276

7. Hoshino Y, Wanatabe H, Yashima Y, Kaneko M, Kumashiro H. An investigation on the sleep disturbance of autistic children. Folia Psychiatr Neurol Jpn (1984) 38:45-51.

8. Johnson CR. Sleep problems in children with mental retardation and autism. Child Adolesc Psychiatr Clin N Am (1996) 5:673-83.

9. Patzold LM, Richdale AL, Tonge BJ. An investigation into sleep characteristics of children with autism and Asperger's disorder. J Paediatr Child Health (1998) 34:528-33. doi:10.1046/j.1440-1754.1998.00291.x

10. Richdale AL, Prior MR. The sleep-wake rhythm in children with autism. Eur Child Adolesc Psychiatry (1995) 4:175-86. doi:10.1007/BF01980456

11. Richdale AL. Sleep problems in autism: prevalence, cause, and intervention. Dev Med Child Neurol (1999) 41:60-6. doi:10.1017/S0012162299000122

12. Schreck KA, Mullick JA. Parental reports of sleep problems in children with autism. J Autism Dev Disord (2000) 30:127-35. doi:10.1023/A:1005407622050

13. Tordjman S, Anderson GM, Kermarrec S, Olivier Bonnot O, Geoffray MM, Brailly-Tabard S, et al. Altered circadian patterns of salivary cortisol in lowfunctioning children and adolescents with autism. Psychoneuroendocrinology (2014) 50:227-45. doi:10.1016/j.psyneuen.2014.08.010

14. Golombek DA, Casiraghi LP, Agostino PV, Paladino N, Duhart JM, Plano SA, et al. The times they're a-changing: effects of circadian desynchronization on physiology and disease. J Physiol Paris (2013) 107(4):310-22. doi:10.1016/j. jphysparis.2013.03.007 
15. Revell VL, Skene DJ. Light-induced melatonin suppression in humans with polychromatic and monochromatic light. Chronobiol Int (2007) 24:1125-35. doi:10.1080/07420520701800652

16. Brown R, Hobson RP, Lee A, Stevenson J. Are there "autistic-like" features in congenitally blind children? J Child Psychol Psychiatry (1997) 38(6):693-703. doi:10.1111/j.1469-7610.1997.tb01696.x

17. Donaldson AI, Heavner KS, Zwolan TA. Measuring progress in children with autism spectrum disorder who have cochlear implants. Arch Otolaryngol Head Neck Surg (2004) 130:666-71. doi:10.1001/archotol.130.5.666

18. Tordjman S, Anderson GM, Bellissant E, Botbol M, Charbuy H, Camus F, et al. Day and nighttime excretion of 6-sulphatoxymelatonin in adolescents and young adults with autistic disorder. Psychoneuroendocrinology (2012) 37:1990-7. doi:10.1016/j.psyneuen.2012.04.013

19. Kulman G, Lissoni P, Rovelli F, Roselli MG, Brivio F, Sequeri P. Evidence of pineal endocrine hypofunction in autistic children. Neuro Endocrinol Lett (2000) 20:31-4.

20. Tordjman S, Anderson GM, McBride PA, Hertzig M, Snow M, Hall L, et al. Plasma beta-endorphin, adrenocorticotropin hormone and cortisol in autism. J Child Psychol Psychiatry (1997) 38(6):705-16. doi:10.1111/j.1469-7610.1997. tb01697.x

21. Ritvo ER, Ritvo R, Yuliwer A, Brothers A, Freeman BJ, Plotkin S. Elevated daytime melatonin concentration in autism. Eur Child Adolesc Psychiatry (1993) 2:75-8. doi:10.1007/BF02098862

22. Nir I, Meir D, Zilber N, Knobler H, Hadjez J, Lerner Y. Brief report: circadian melatonin, thyroid-stimulating hormone, prolactin, and cortisol levels in serum of young adults with autism. J Autism Dev Disord (1995) 25:641-54. doi:10.1007/BF02178193

23. Tordjman S, Anderson GM, Pichard N, Charbuy H, Touitou Y. Nocturnal excretion of 6-sulphatoxymelatonin in children and adolescents with autistic disorder. Biol Psychiatry (2005) 57:134-8. doi:10.1016/j.biopsych.2004. 11.003

24. Melke J, Goubran Botros H, Chaste P, Betancur C, Nygren G, Anckarssater H, et al. Abnormal melatonin synthesis in autism spectrum disorder. Mol Psychiatry (2008) 13(1):90-8. doi:10.1038/sj.mp.4002016

25. Mulder EJ, Anderson GM, Kemperman RFJ, Oosterloo-Duinkerken A, Minderaa RB, Kema IP. Urinary excretion of 5-hydroxyindoleacetic acid, serotonin and 6-sulphatoxymelatonin in normoserotonemic and hyperserotonemic autistic individuals. Neuropsychobiology (2010) 61:27-32. doi:10.1159/ 000258640

26. Tordjman S, Najjar I, Bellissant E, Anderson GM, Barburoth M, Cohen D, et al. Advances in the research of melatonin in autism spectrum disorders: literature review and new perspectives. Int J Mol Sci (2013) 14(10):20508-42. doi:10.3390/ijms141020508

27. Amiet C, Gourfinkel-An I, Bouzamondo A, Tordjman S, Baulas M, Lechat $\mathrm{P}$, et al. Epilepsy in autism is associated with intellectual disability and gender: evidence from a meta-analysis. Biol Psychiatry (2008) 64(7):577-82. doi:10.1016/j.biopsych.2008.04.030

28. Hu VW, Sarachana T, Kim KS, Nguyen A, Kulkarni S, Steinberg ME, et al. Gene expression profiling differentiates autism case-controls and phenotypic variants of autism spectrum disorders: evidence for circadian rhythm dysfunction in severe autism. Autism Res (2009) 2:78-97. doi:10.1002/aur.73

29. Jansen R, Metzdorf R, Van der Roest M, Fusani L, ter Maat A, Gahr M. Melatonin affects the temporal organization of the song of the zebra finch. FASEB $J$ (2005) 19:848-50. doi:10.1096/fj.04-2874fje

30. Boucher J. Lost in a sea of time: Time parsing and autism. In: Hoerl C, McCormack T, editors. Time and Memory: Issues in Philosophy and Psychology. Oxford: Oxford University Press (2001). p. 111-36.

31. Wimpory D, Nicholas B, Nash S. Social timing clock genes and autism: a new hypothesis. J Intellect Disabil Res (2002) 46:352-8. doi:10.1046/j.1365-2788. 2002.00423.x

32. Weisman O, Zagoory-Sharon O, Feldman R. Oxytocin administration to parent enhances infant physiological and behavioral readiness for social engagement. Biol Psychiatry (2012) 72:982-9. doi:10.1016/j.biopsych.2012.06.011

33. Insel TR. Oxytocin - a neuropeptide for affiliation: evidence from behavioral, receptor autoradiographic, and comparative studies. Psychoneuroendocrinology (1992) 17(1):3-35. doi:10.1016/0306-4530(92)90073-G

34. Modahl C, Fein D, Waterhouse L, Newton N. Does oxytocin deficiency mediate social deficits in autism? J Autism Dev Disord (1992) 2(3):449-51. doi:10.1007/BF01048246
35. Modahl C, Green LA, Fein D, Morris M, Waterhouse L, Feinstein C, et al. Plasma oxytocin levels in autistic children Biol. Psychiatry (1998) 43(4):270-7.

36. Guedeney A, Guedeney N, Tereno S, Dugravier R, Greacen T, Welniarz B, et al. Infant rhythms versus parental time: promoting parent-infant synchrony. $J$ Physiol Paris (2011) 105(4-6):195-200. doi:10.1016/j.jphysparis.2011.07.005

37. Lickliter R, Bahrick LE, Honeycutt $H$. Intersensory redundancy facilitates prenatal perceptual learning in bobwhite quail (Colinus virginianus) embryos. Dev Psychol (2002) 38:15-23. doi:10.1037/0012-1649.38.1.15

38. Tordjman S. At the crossroads between psychoanalysis and neuroscience: the importance of subjectivity. J Physiol Paris (2010) 104(5):232-42. doi:10.1016/ j.jphysparis.2010.08.001

39. Wallon H. L'enfant Turbulent. Paris: PUF (1984).

40. Haag G, Botbol M, Graignic R, Perez-Diaz F, Bronsard G, Kermarrec S, et al. The autism psychodynamic evaluation of changes (APEC) scale: a reliability and validity study on a newly developed standardized psychodynamic assessment for youth with pervasive developmental disorders. J Physiol Paris (2010) 104(6):323-36. doi:10.1016/j.jphysparis.2010.10.002

41. Price DA, Close GC, Fielding BA. Age of appearance of circadian rhythm in salivary cortisol values in infancy. Arch Dis Child (1983) 58:454-6. doi:10.1136/ adc.58.6.454

42. Joseph D, Chong NW, Shanks ME, Rosato E, Taub NA, Petersen SA, et al. Getting rhythm: how do babies do it? Arch Dis Child Fetal Neonatal Ed (2014) 100(1):F50-4. doi:10.1136/archdischild-204-306104

43. Lavelli M, Fogel A. Developmental changes in the relationship between the infant's attention and emotion during early face-to-face communication: the 2month transition. Dev Psychol (2005) 41(1):265. doi:10.1037/0012-1649.41.1. 265

44. Trevarthen C, Aitken KJ. Infant intersubjectivity: research, theory, and clinical applications. J Child Psychol Psychiatry (2001) 2:3-48. doi:10.1111/1469-7610. 00701

45. Shultz S, Vouloumanos A, Bennett RH, Pelphrey K. Neural specialization for speech in the first months of life. Dev Sci (2014) 17(5):766-74. doi:10.1111/ desc. 12151

46. Meltzoff AN, Kuhl PK, Movellan J, Sejnowski TJ. Foundations for a new science of learning. Science (2009) 325:284-8. doi:10.1126/science.1175626

47. Kuhl PK. Early language acquisition: cracking the speech code. Nat Rev Neurosci (2004) 5:831-43. doi:10.1038/nrn1533

48. Goldstein MH, King AP, West MJ. Social interaction shapes babbling: testing parallels between birdsong and speech. Proc Natl Acad Sci U S A (2003) 100:8030-5. doi:10.1073/pnas.1332441100

49. Delaherche E, Chetouani M, Mahdhaoui A, Saint-Georges C, Viaux S, Cohen D. Interpersonal synchrony: a survey of evaluation methods across disciplines. IEEE Trans Affect Comput (2012) 3:349-65. doi:10.1109/T-AFFC.2012.12

50. Crown CL, Feldstein S, Jasnow MD, Beebe B, Jaffe J. The cross-modal coordination of interpersonal timing: six-week-olds infants' gaze with adults' vocal behavior. J Psycholinguist Res (2002) 31(1):1-23. doi:10.1023/A: 1014301303616

51. Stormark KM, Braarud HC. Infants' sensitivity to social contingency: a "double video" study of face-to-face communication between 2-and 4-month-olds and their mothers. Infant Behav Dev (2004) 27(2):195-203. doi:10.1016/j.infbeh. 2003.09.004

52. Feldman R. Parent-infant synchrony and the construction of shared timing; physiological precursors, developmental outcomes, and risk conditions. J Child Psychol Psychiatry (2007) 48(3-4):329-54. doi:10.1111/j.1469-7610. 2006.01701.x

53. Dumas GJ, Nadel R, Soussignan J, Martinerie L, Garnero L. Inter-brain synchronization during social interaction. PLoS One (2010) 5(8):e12166. doi:10.1371/journal.pone.0012166

54. Saint-Georges C, Mahdhaoui A, Chetouani M, Cassel R, Laznik MC, Apicella F, et al. Do parents recognize autistic deviant behavior long before diagnosis? Taking into account interaction using computational methods. PLoS One (2011) 6(7):e22393. doi:10.1371/journal.pone.0022393

55. Guinchat V, Chamak B, Bonniau B, Bodeau N, Perisse D, Cohen D, et al. Very early signs of autism reported by parents include many concerns not specific to autism criteria. Res Autism Spectr Disord (2012) 6:589-601. doi:10.1016/j.rasd.2011.10.005

56. Zwaigenbaum L, Bryson S, Rogers T, Roberts W, Brian J, Szatmari P. Behavioral manifestations of autism in the first year of life. Int J Dev Neurosci (2005) 23(2-3):143-52. doi:10.1016/j.ijdevneu.2004.05.001 
57. Elsabbagh M, Johnson MH. Getting answers from babies about autism. Trends Cogn Sci (2010) 14(2):81-7. doi:10.1016/j.tics.2009.12.005

58. Stern D. Le monde interpersonnel du nourrisson. Paris: PUF (1989).

59. Cohen D, Cassel RS, Saint-Georges C, Mahdhaoui A, Laznik MC, Apicella F, et al. Do parentese prosody and fathers' involvement in interacting facilitate social interaction in infants who will later develop autism? PLoS One (2013) 8(5):e61402. doi:10.1371/journal.pone.0061402

60. Watanabe K. Behavioral speed contagion: automatic modulation of movement timing by observation of body movements. Cognition (2008) 106:514-24. doi:10.1016/j.cognition.2007.06.001

61. Mauk MD, Buonomano DV. The neural basis of temporal processing. Annu Rev Neurosci (2004) 27:307-40. doi:10.1146/annurev.neuro.27.070203.144247

62. Xavier J, Tilmont E, Bonnot O. Children's synchrony and rhythmicity in imitation of peers: toward a developmental model of empathy. J Physiol Paris (2013) 107(4):291-7. doi:10.1016/j.jphysparis.2013.03.012

63. Trevarthen C. what is like to be a person who knows nothing? Defining the active intersubjective mind of a newborn human being. Infant Child Dev (2011) 20:119-35. doi:10.1002/icd.689

64. Nadel J. Imiter Pour Grandir. Développement du bébé et de l'enfant avec autisme. Paris: Dunod (2011).

65. Nadel-Brulfert J, Baudonnière PM. The social function of reciprocal imitation in 2-years-old peers. Int J Behav Dev (1982) 5:95-109. doi:10.1177/ 016502548200500105

66. Nadel J, Baudonnière PM, Fontaine AM. Les comportements sociaux imitatifs. Recherches Psychologie Sociale (1983) 5:15-29.

67. Ikegami T, Iizuka H. Turn-taking interaction as acooperative and co-creative process. Infant Behav Dev (2007) 30:278-88. doi:10.1016/j.infbeh.2007.02.002

68. Rizzolatti G, Craighero L. The mirror-neuron system. Annu Rev Neurosci (2004) 27:169-92. doi:10.1146/annurev.neuro.27.070203.144230

69. Guionnet S, Nadel J, Bertasi E, Sperduti M, Delaveau P, Fossati P. Reciprocal imitation: toward a neural basis of social interaction. Cereb Cortex (2012) 22:971-8. doi:10.1093/cercor/bhr177

70. Decety J, Chaminade T, Grezes J, Meltzoff AN. A PET exploration of the neural mechanisms involved in reciprocal imitation. Neuroimage (2002) 15:265-72. doi:10.1006/nimg.2001.0938

71. Iacoboni M. Neural mechanisms of imitation. Curr Opin Neurobiol (2005) 15:632-7. doi:10.1016/j.conb.2005.10.010

72. Nettl B. An ethnomusicologist contemplates universals in musical sound and musical culture. In: Wallin NL, Merker B, Brown S, editors. The Origins of Music. Cambridge, MA: MIT Press (2000). p. 463-72.

73. Patel AD, Iversen JR, Bregman MR, Schulz I. Experimental evidence for synchronization to a musical beat in a nonhuman animal. Curr Biol (2009) 19:827-30. doi:10.1016/j.cub.2009.03.038

74. Feldman R. Parent-infant synchrony biological foundations and developmental outcomes. Curr Dir Psychol Sci (2007) 16:340-5. doi:10.1111/j.1467-8721. 2007.00532.x

75. Winkler I, Háden GP, Ladinig O, Sziller I, Honing H. Newborn infants detect the beat in music. Proc Natl Acad Sci U S A (2009) 106:2468-71. doi:10.1073/pnas.0809035106

76. Provasi J, Bobin-Begue A. Spontaneous motor tempo and rhythmical synchronisation in 2-1/2 and 4-year-old children. Int J Behav Dev (2003) 27:220-31. doi:10.1080/01650250244000290

77. Bobin-Bègue A, Provasi J, Marks A, Pouthas V. Influence of an auditory tempo on the endogenous rhythm of non-nutritive sucking. Eur Rev Appl Psychol (2006) 56:239-45. doi:10.1016/j.erap.2005.09.006

78. Trevarthen C, Stuart Daniel S. Disorganized rhythm and synchrony: early signs of autism and Rett syndrome. Brain Dev (2005) 27:S25-34. doi:10.1016/j. braindev.2005.03.016

79. Sandercock R, Jones W, Klin A, Shultz S. Contingent smiling behavior in 2- to 5-month-old infants with and without ASD during dyadic interactions. International Meeting for Autism Research (IMFAR). Atlanta, GA (2015).

80. Jones W, Klin A. Attention to eyes is present but in decline in 2-6-monthold infants later diagnosed with autism. Nature (2013) 504(7480):4427-31. doi:10.1038/nature12715

81. American Psychiatric Association. Diagnostic and Statistical Manual of Mental Disorders, Fifth Edition (DSM-5). 5th ed. Washington, DC: American Psychiatric Association (2013).

82. Malow B, Adkins K, McGrew S, Wang L, Goldman S, Fawkes D. Melatonin for sleep in children with autism: a controlled trial examining dose, tolerability and outcomes. J Autism Dev Disord (2011) 42(8):1729-37. doi:10.1007/s10803011-1418-3

83. Goldbeter A. La vie Oscillatoire. Paris: Odile Jacob (2010).

84. Winnicott DW. Collected Papers: Through Pediatrics to Psychoanalysis. London: Tavistock Publications (1958).

85. Fureix C, Benhajali H, Henry S, Bruchet A, Prunier A, Ezzaouia M, et al. Plasma cortisol and faecal cortisol metabolites concentrations in stereotypic and nonstereotypic horses: do stereotypic horses cope better with poor environmental conditions? BMC Vet Res (2013) 9:3. doi:10.1186/1746-6148-9-3

86. Gabriels RL, Agnew JA, Pan Z, Holt KD, Reynolds A, Laudensiager ML. Elevated repetitive behaviors are associated with lower diurnal salivary cortisol levels in autism spectrum disorder. Biol Psychol (2013) 93(2):262-8. doi:10.1016/j.biopsycho.2013.02.017

87. Adler BA, Wink LK, Early M, Shaffer R, Minshawi N, McDougle CJ, et al. Drug-refractory aggression, self-injurious behavior, and severe tantrums in autism spectrum disorders: a chart review study. Autism (2015) 19(1):102-6. doi:10.1177/1362361314524641

88. Minshawi NF, Hurwitz S, Morriss D, McDougle CJ. Multidisciplinary assessment and treatment of self-injurious behavior in autism spectrum disorder and intellectual disability: integration of psychological and biological theory and approach. J Autism Dev Disord (2014). doi:10.1007/s10803014-2307-3

89. Stigler KA. Psychopharmacologic management of serious behavioral disturbance in ASD. Child Adolesc Psychiatr Clin N Am (2014) 23(1):73-82. doi:10.1016/j.chc.2013.07.005

90. Horrigan JP, Barnhill LJ. More on melatonin. J Am Acad Child Adolesc Psychiatry (1997) 36(8):1014. doi:10.1097/00004583-199708000-00002

91. Hayashi E. Effect of melatonin on sleep-wake rhythm: the sleep diary of an autistic male. Psychiatry Clin Neurosci (2000) 54:383-4. doi:10.1046/j.14401819.2000.00725.x

92. Jan JE, Freeman RD, Wasdell MB, Bomben MM. A child with severe night terrors and sleep-walking responds to melatonin therapy'. Dev Med Child Neurol (2004) 46(11):789. doi:10.1017/S0012162204231358

93. Gupta R, Hutchins J. Melatonin: a pancea for desperate parents? (Hype or truth). Arch Dis Child (2005) 90(9):986-7. doi:10.1136/adc.2005. 075218

94. Andersen IM, Kaczmarska J, McGrew SG, Malow BA. Melatonin for insomnia in children with autism spectrum disorders. J Child Neurol (2008) 23(5):482-5. doi:10.1177/0883073807309783

95. Galli-Carminati G, Deriaz N, Bertschy G. Melatonin in treatment of chronic sleep disorders in adults with autism: retrospective study. Swiss Med Wkly (2009) 139(19-20):293-6.

96. Jan JE, Espezel H, Appleton RE. The treatment of sleep disorders with melatonin. Dev Med Child Neurol (1994) 36:97-107. doi:10.1111/j.1469-8749.1994. tb11818.x

97. Ishizaki A, Sugama M, Takeuchi N. Usefulness of melatonin for developmental sleep and emotional/behaviour disorders - studies of melatonin trial on 50 patients with developmental disorders. No To Hattatsu (1999) 31(5): 428-37.

98. Paavonen EJ, Nieminen-von Wendt T, Vanhala R, Aronen ET, von Wendt L. Effectiveness of melatonin in the treatment of sleep disturbances in children with Asperger disorder. J Child Adolesc Psychopharmacol (2003) 13(1): 83-95. doi:10.1089/104454603321666225

99. Giannotti F, Cortesi F, Cerquiglini A, Bernabei P. An open-label study of controlled-release melatonin in treatment of sleep disorders in children with autism. J Autism Dev Disord (2006) 36(6):741-52. doi:10.1007/s10803-0060116-z

100. De Leersnyder H, Zisapel N, Laudon M. Prolonged-release melatonin for children with neurodevelopmental disorders. Pediatr Neurol (2011) 45:23-6. doi:10.1016/j.pediatrneurol.2011.02.001

101. MacArthur AJ, Budden SS. Sleep dysfonction in Rett syndrome: a trial of exogenous melatonin treatment. Dev Med Child Neurol (1998) 40:186-92. doi:10.1111/j.1469-8749.1998.tb15445.x

102. Garstang J, Wallis M. Randomized controlled trial of melatonin for children with autistic spectrum disorders and sleep problems. Child Care Health Dev (2006) 32(5):585-9. doi:10.1111/j.1365-2214.2006.00616.x

103. Wasdell MB, Jan JE, Bomben MM, Freeman RD, Rietveld WJ, Tai J, et al. A randomized, placebo-controlled trial of controlled release melatonin treatment of delayed sleep phase syndrome and impaired sleep maintenance in 
children with neurodevelopmental disabilities. J Pineal Res (2008) 44(1):57-64. doi:10.1111/j.1600-079X.2007.00528.x

104. Wirojanan J, Jacquemont S, Diaz R, Bacalman S, Anders TF, Hagerman RJ, et al. The efficacy of melatonin for sleep problems in children with autism, fragile X syndrome, or autism and fragile X syndrome. J Clin Sleep Med (2009) 5(2): 145-50.

105. Wright B, Sims D, Smart S, Alwazeer A, Alderson-Day B, Allgar V, et al. Melatonin versus placebo in children with autism spectrum conditions and severe sleep problems not amenable to behaviour. management strategies: a randomised controlled crossover trial. J Autism Dev Disord (2011) 41(2):175-84. doi:10.1007/s10803-010-1036-5

106. Cortesi F, Giannotti F, Sebastiani T, Panunzi S, Valente D. Controlled-release melatonin, singly and combined with cognitive behavioural therapy, for persistent insomnia in children with autism spectrum disorders: a randomized placebo-controlled trial. J Sleep Res (2012) 21(6):700-9. doi:10.1111/j.13652869.2012.01021.x

107. Gringas P, Gamble C, Jones AP, Wiggs L, Williamson PR, Sutcliffe A, et al. Melatonin for sleep problems in children with neurodevelopmental disorders: randomised double masked placebo controlled trial. BMJ (2012) 345:1-16. doi:10.1136/bmj.e6664

108. Jan JE, O'Donnel ME. Use of melatonin in the treatment of paediatric sleep disorders. J Pineal Res (1996) 21:193-9. doi:10.1111/j.1600-079X.1996.tb00286.x

109. Jan JE, Connolly MB, Hamilton D, Freeman RD, Laudon M. Melatonin treatment of non-epileptic myoclonus in children. Dev Med Child Neurol (1999) 41(4):255-9. doi:10.1111/j.1469-8749.1999.tb00593.x

110. Phillips L, Appleton RE. Systematic review of melatonin treatment in children with neurodevelopmental disabilities and sleep impairment. Dev Med Child Neurol (2004) 46:771-5. doi:10.1017/S001216220400132X

111. Braam W, Smits MG, Didden R, Korzilius H, Van Geijlswijk M, Curfs LMG. Exogenous melatonin for sleep problems in individuals with intellectual disability: a meta-analysis. Dev Med Child Neurol (2009) 51:340-9. doi:10.1111/j.1469-8749.2008.03244.x

112. Guénolé F, Godbout R, Nicolas A, Franco P, Claustrat B, Baleyte JM. Melatonin for disordered sleep in individuals with autism spectrum disorders: systematic review and discussion. Sleep Med Rev (2011) 15(6):379-87. doi:10.1016/j.smrv. 2011.02.001

113. Doyen C, Mighiu D, Kaya K, Colineaux C, Beaumanoir C, Mouraeff Y, et al. Melatonin in children with autistic spectrum disorders: recent and practicaldata. Eur Child Adolesc Psychiatry (2011) 20(5):231-9. doi:10.1007/s00787011-0162-8

114. Rossignol DA, Frye RE. Melatonin in autism spectrum disorders: a systematic review and meta-analysis. Dev Med Child Neurol (2011) 53:783-92. doi:10.1111/j.1469-8749.2011.03980.x

115. Reading R. Melatonin in autism spectrum disorders: a systematic review and meta-analysis. Child Care Health Dev (2012) 38(2):301-2.

116. Guénolé F, Baleyte JM. Meta-analysing the effectiveness of melatonin for sleepdisturbed individuals with autism spectrum conditions: should Rett syndrome be included? Dev Med Child Neurol (2011) 53(11):1063. doi:10.1111/j.14698749.2011.04071.x
117. Guénolé F, Baleyte JM. Effects of melatonin should be studied separately in each neurodevelopmental disorder and with specific sleep diagnoses. Pediatr Neurol (2012) 46(1):60. doi:10.1016/j.pediatrneurol.2011.11.001

118. Lord C. What is melatonin? Is it a useful treatment for sleep problems in autism? J Autism Dev Disord (1998) 28(4):345-6. doi:10.1023/A:1026020600723

119. Dawson G, Rogers SJ, Munson J, Smith M, Winter J, Greenson J, et al. Randomized controlled trial of an intervention for toddlers with autism: the early start Denver model. Pediatrics (2010) 25(1):e17-23. doi:10.1542/peds.2009-0958

120. Rogers SJ, Dawson G. Early Start Denver Model for Children with Autism: Promoting Language, Learning, and Engagement. New York, NY: Guilford Press (2010).

121. Feldman R, Masalha S. Parent-child and triadic antecedents of children's social competence: cultural specificity, shared process. Dev Psychol (2010) 46(2):455-67. doi:10.1037/a0017415

122. Leerkes EM, Blankson AN, O'Brien M. Differential effects of maternal sensitivity to infant distress and nondistress on social-emotional functioning. Child Dev (2009) 80(3):762-75. doi:10.1111/j.1467-8624.2009.01296.x

123. Paavola L, Kemppinen K, Kumpulainen K, Moilanen I, Ebeling H. Maternal sensitivity, infant co-operation and early linguistic development: some predictive relations. Eur J Dev Psychol (2006) 3(1):13-30. doi:10.1080/ 17405620500317789

124. Shonkoff JP, Phillips DA, editors. From Neurons to Neighborhoods: The Science of Early Childhood Development. Washington, DC: National Academy Press (2000).

125. Lewy A, Dawson G. Social stimulation and joint attention deficits in young autistic children. J Abnorm Child Psychol (1992) 20:555-66. doi:10.1007/ BF00911240

Conflict of Interest Statement: The authors declare that the research was conducted in the absence of any commercial or financial relationships that could be construed as a potential conflict of interest.

Received: 20 August 2014; accepted: 05 January 2015; published online: 23 February 2015.

Citation: Tordjman S, Davlantis KS, Georgieff N, Geoffray M-M, Speranza M, Anderson GM, Xavier J, Botbol M, Oriol C, Bellissant E, Vernay-Leconte J, Fougerou C, Hespel A, Tavenard A, Cohen D, Kermarrec S, Coulon N, Bonnot O and Dawson $G$ (2015) Autism as a disorder of biological and behavioral rhythms: toward new therapeutic perspectives. Front. Pediatr. 3:1. doi: 10.3389/fped.2015.00001

This article was submitted to Child and Neurodevelopmental Psychiatry, a section of the journal Frontiers in Pediatrics.

Copyright (๑ 2015 Tordjman, Davlantis, Georgieff, Geoffray, Speranza, Anderson, Xavier, Botbol, Oriol, Bellissant, Vernay-Leconte, Fougerou, Hespel, Tavenard, Cohen, Kermarrec, Coulon, Bonnot and Dawson. This is an open-access article distributed under the terms of the Creative Commons Attribution License (CC BY). The use, distribution or reproduction in other forums is permitted, provided the original author(s) or licensor are credited and that the original publication in this journal is cited, in accordance with accepted academic practice. No use, distribution or reproduction is permitted which does not comply with these terms. 